\title{
The Effect of Power Base Games on Organizational Silence and Organizational Socialization
}

\author{
Muharrem Gencer ${ }^{1}$, Türkay Nuri Tok ${ }^{2}$, Aydan Ordu ${ }^{3, *}$ \\ ${ }^{1}$ Ministry of National Education, Burdur, Turkey \\ ${ }^{2}$ Department of Educational Sciences, Izmir Democracy University, Izmir, Turkey \\ ${ }^{3}$ Department of Educational Sciences, Pamukkale University, Denizli, Turkey
}

Copyright $(\mathrm{O} 2018$ by authors, all rights reserved. Authors agree that this article remains permanently open access under the terms of the Creative Commons Attribution License 4.0 International License

\begin{abstract}
The purpose of this study was to analyze the effect of power base games used by school principals on teachers' organizational silence and on their organizational socialization according to teacher perceptions. The sample of the study consisted of 468 teachers working in the city center of Burdur province in the 2016-2017 educational year. The data was collected through "Power Base Games Scale", "Organizational Silence Scale" and "Organizational Socialization Scale". Descriptive statistics, t-test, one-way variance analysis and Structural Equation Model were used for the analysis of the data. According to the results of the study, among the Power Base Games; Lording and Alliance Building Games have a positive effect, but Sponsorship Game has a negative effect on organizational silence; Empire Building, Expertise and Budgeting Games have no effect on organizational silence. Lording and Sponsorship Games, on the other hand, have a negative effect on organizational socialization; Alliance Building, Empire Building, Expertise and Budgeting Games have no effect on organizational socialization.
\end{abstract}

Keywords Political Games, Power Base Games, Organizational Silence, Organizational Socialization

\section{Introduction}

It has become more difficult for organizations, characterized as structured social entities for achieving specific goals, to sustain their assets in the globalizing world. To survive, organizations have to adapt to changes and developments and compete with other organizations. Within this period, employees also struggle among themselves by displaying political behaviours because of their personal interests, such as the distribution of scarce resources and future concerns. Gibson, Ivancevich and Donnelly [1] have described political behaviour as the behaviour of a person outside of the normal power system for his own benefit or for another unit's benefit and they have indicated that individuals and units in organizations are constantly engaged in political behaviours. Although political behaviour at a high level is unlikely to occur in the organizations that have adopted clear and distinct decision-making processes and that have less competitive behaviour [2], it is seen as an indispensable part of organizational life. According to Samuel [3], organizations are regarded as political arenas in which individuals and groups struggle to increase their own interests, albeit at the expense of the organization. For this reason, the political aspect of the organizations represents a certain degree of hidden side of the organization. The concept of politics has two different meanings in the literature. The first of these is "policy"; it is the body of principles that guides the decisions and implementations of the organization. The second is "politics"; unlike the first meaning, it is every kind of behaviour that envisages influencing the other side. Therefore, power lies in the basis of the second politics concept; it aims to achieve the desired change on the opposite side through power [4]. Many authors have noted that the power phenomenon is the main feature of the issue, which can often be used instead of the concept of organizational politics [5]. The concept of "power" which is at the center of the interest of mankind for management and organization can be defined as a resource (a kind of force reserve) used by someone effective to change the behaviour of another individual [6].

Political games, the means of applying political behaviour, are played according to complex, intertwined and subtle tactics and rules. The rules of the game are sometimes clear; sometimes quite explicit, sometimes ambiguous; sometimes stable, sometimes changeable; but all the rules determine the nature of the game [7]. Mintzberg [8] categorizes political games into four categories; authority games, power base games, rival games and change games. Among these games, power base games can be defined as the games played in parallel with the power in order to increase the organizational power of 
the individual [2]. Mintzberg [8] categorizes power base games, in which employees utilize all opportunities in order to reach their personal goals, into six categories as 'sponsorship', 'alliance building', 'empire building', 'budgeting', 'expertise' and 'lording'. Sponsorship game involves a person who attaches himself to a rising or an established star. Employees play this game by reporting their loyalty to their superiors in return for power and thus by taking advantage of the superiors [9]. Alliance building game is played among peers who seek mutual support [10]. It is generally played by functional executives who implicitly contract to support each other in progress within the organization and sometimes played by experts [11]. Empire building game is played individually by managers in cooperation with subordinates [11]. The game is played with the aim of increasing their power by bringing subordinates and subunits together and using their potentials [7]. The main purpose of budgeting game is to secure disproportionate share of unallocated total resources and use them for a specific group [7]. Players are the responsible persons in the budgeting areas [12]. In the expertise game, experts try to secure their positions by using their special knowledge [10]. The game is played by the individuals who have the technical skills or expertise required for the organization [11]. In lording game, individuals try to gain power by using their legal power over subordinates [10]. The persons who are unable to play the political games or refuse to use these games are generally the people who feel the negative effects of large-scale political games. Examples of these negative effects are the decrease in job satisfaction, the increase in anxiety and stress, the tendency to leave work and the decrease in performance [13]. Because the stress level of the employees will be high in the environments where organizational politics perceptions are high $[5,14,15]$, employees avoid to use their knowledge, skills and talents to realize the goals of the organization. In addition, in the formal and informal communication channels, hiding the information, guiding it consciously, providing the flow of information in the direction of individual requests, using the data to support the views of individuals and limiting the real aims of communication are both the reasons and consequences of political games [5].

In the globalized world, technological, educational and economic developments have increased the need for the employees who will successfully let the organizations reach their goals, who generate new thinking and voice current problems. However, it is asserted that in many organizations, there are effective forces causing employees to hide information about potential problems or issues [16]. This situation reduces the contribution of employees, the most important shareholder of the organization, and puts the organization into a stable structure. Organizational silence, defined as individual's denying his behavioral, cognitive and affective evaluations about organizational situations, is a dynamic process that progresses and forms as a reaction to various individual and situational factors [17]. Studies on the subject show that employees may prefer silence because of the following reasons; organizational stress [18], negative managerial behaviours $[19,20]$, fear of punishment, lack of experience, being external audit-oriented, culture of injustice, silence climate, social isolation, obedience culture, distrust to superiors, arm's length relationships and anxiety of being labeled as a problem person [21]. When researchers' studies on the concept of silence are examined, it is seen that they classify silence differently. Subkowiak (1997) classifies silence as acoustic silence and pragmatic silence; Bruneau (1973) classifies it as psycholinguistics, interactive and sociocultural silence [cited in 17]. Pinder and Harlos [17], on the other hand, classify silence into two groups as passiveness and acquiescent. Improving silence classification by Pinder and Harlos [17]; Van Dyne, Ang and Botero [22] classify silence into three groups as 'acquiescent silence', 'defensive silence' and 'prosocial silence'. Tolerance to the status quo is high in the acquiescent silence which is defined as the denying of ideas, information and thoughts based on submission [22]. Employees keep their ideas, knowledge and thoughts about an issue to themselves because of fear in the defensive silence which is a conscious and proactive behaviour towards self-protection against external threats [18]. Prosocial silence is defined as the denying of ideas, knowledge and thoughts related to work for the benefit of organization or other employees based on sacrifice or common motivation [22]. The deliberate denying of knowledge by employees and its becoming a process leads to many individual and organizational outcomes. Chronic employee silence in organizations reduces work efficiency by causing employees to experience emotional exhaustion, depersonalization, decrease in personal achievement [23], alienation and emotional exhaustion [24, 25]. Keep silent pressures the differences under the surface and drives the destructive forces strongly. However, breaking silence can cause to express fresh ideas and can bring ideas that may improve the organizational performance to an entirely new level [26].

Organizations are able to gain competitive advantage through the ability of selecting, educating and retaining human resources effectively. For this reason, the issue of adaptation of hired employees is becoming increasingly important. The effective basic concept in the adaptation process is seen as the organizational socialization. Organizational socialization gets employees to become an active member of the organization - through various stages and tactics - by facilitating their adaptation to the values, norms and needs of the entity [27]. For this reason, organizational socialization has always been one of the focuses of experts in behaviour and human resources [28]. Organizational socialization, a process of learning and change, includes organizational values, goals, culture, workgroup values, norms, how to perform the job, 
necessary knowledge and skills, identity, self-esteem, personal change and motivation [29]. Organizations should apply different patterns and different strategies in the socialization of new employees in accordance with their own structures [30]. Taormina [31] has developed a model that explains organizational socialization in four dimensions: 'training', 'understanding of one's job and organization', 'coworker support' and 'future prospects'. Training can be defined as an action, process or method that gives any form of functional skill or ability that a specific job requires [32]. The aim of the training in organizations is improving the satisfaction of the employees in their work, the efficiency of the individual and the performance of the organization as a whole [33]. Understanding dimension measures how well the employee understands the organization, how it works and how he himself works within the organization [34]. The dimension forms the basis of employee behaviour, which is also including information seeking. The main purpose of the employee's search for information is to understand their own work, their roles, their colleagues, organization's goals, values and culture much better [32]. Coworker support identifies how well the employee is related to other employees within the organization [34]. In other words, coworker support is defined as emotional, spiritual or instrumental support provided by other employees in the organization in order to reduce person's anxiety, fear or suspicion [32]. Future prospects determine the long-term perspective of the employee, such as the prizes offered by the organization and ongoing employment expectation [34]. It may also include profits such as promotions, bonuses, recognition, allowances and the assignment to the desired duties [35]. When effective socialization programs are designed according to the expectations of employees in organizations, organizational socialization can reduce the cost by creating a positive impact on organizational commitment and a negative impact on the tendency to leave work [36]. Organizational socialization increases the employee's commitment to work [28, 37-41], dedication to work [40, 42], and job satisfaction [43-45]. Besides, according to Jaskyte [46], socialization tactics prevent role ambiguity and conflict in organizations.

Schools which are an open system have a special status in society due to the functions they undertake. School affects the society in which it is located and it is influenced by changes in society. In this context, political games are also used in school life much more than generally accepted. The approach that defines school as an organization formed on the basis of power relations is called as micro politics [47]. Micro political processes and structures allow some individuals and groups more than others. Especially in the processes of change, the micro political interaction increases and becomes more prominent in both formal and informal arenas of school life. Micro politics affects all decision-making structures and processes in school environment [48]. It can be argued that the most important actors of micro politics, which has become increasingly important in schools in recent years [47], are school principals. Because, based on the authority given to him, the person primarily responsible for the realization of the purposes of the schools is the school principal. Leadership features of the school principal affect the effectiveness of the school [49], student success [50], and the organizational trust, loyalty and citizenship felt at school directly and significantly [51]. Principals who use effective leadership behaviours with constructive political behaviours can lead teachers to act in a way that will achieve the goals of the school. Political games have a critical importance especially for managers because it deals with the process of transforming power, which has the potential to affect others in a successful way, into action. Principals who display constructive political behavior know how to shape the agenda, how to prepare the roadmap in political arena, how to create a support network, and how to negotiate with both allies and opponents [52]. For this reason, if the school principal has sufficient knowledge and experience about in which conditions, in what environment, when, to what extent and with which stimuli a teacher can be motivated and behaves properly as a political actor, the chances of improving organizational integration and working efficiency will increase. It is necessary for school principals to prevent teachers' silence behaviour and achieve their organizational socialization through using political games, a part of organizational life, effectively. However, it appears that there is not enough information about how to use political games in organizations and especially in schools and about required competencies for successful examples [53]. When literature is analyzed, organizational politics and political behaviours have been studied by many researchers over the past 40 years as it is a way of life in organizations [54]. However, studies on political games are very limited $[8,9$, $10,12,55,56]$ and to be more precise, no studies have been found on power base games. On the basis of all these evaluations, the main purpose of this study is what the effects of the power base games used by school principals will be on teachers' organizational silence and organizational socialization. In accordance with this purpose, the answers to the following questions are searched:

1. What is the level of teacher perceptions regarding power base games used by school principals, organizational silence and organizational socialization?

2. Do teachers' perceptions of power base games used by school principals, organizational silence and organizational socialization differ significantly in terms of gender, branch, occupational seniority and length of service at school variables?

3. Do the perceptions of teachers about power base games used by school principals significantly 
predict their perceptions of organizational silence and organizational socialization?

\section{Method}

The research was designed in a relational survey model. In a relational survey model, the aim is to determine the presence or the degree of covariance at least between two variables [57]. The population of the research consisted of 1316 teachers working in Burdur province center in the academic year of 2016-2017. The sample of the research was determined by "random sampling" method. In determining the number of sample, the formula [cited in 58] proposed by Cochran (1962) was used and the needed sample size was calculated as 297 . The entire population was tried to be reached by considering the possibilities that the whole of the scales were not returned or they were incomplete or incorrect, and 468 teachers created the sample of the study. Of the participants, $262(56.0 \%)$ were female and $206(44.0 \%)$ were male teachers; $77(16.5 \%)$ were non-math courses, 139 (29.7\%) were math and science courses, $130(27.8 \%)$ were classroom and 122 (26.1\%) were other branch teachers. $156(33.3 \%)$ of teachers had $1-10$ years, $155(33.1 \%)$ of them had 11-20 years and $157(33.5 \%)$ of them 21 and over years of seniority. In terms of the length of service at the school that they currently work, $310(66.2 \%)$ of the teachers had 1-5 years of service, $96(20.5 \%)$ of them had 6-10 years and 62 $(13.2 \%)$ of them had 11 and over years of service.

\subsection{Data Collection Tools}

Data required for the research were collected by "Power Base Games Scale", "Organizational Silence Scale" and "Organizational Socialization Scale".

\subsubsection{Power Base Games Scale}

This measuring instrument is used to measure the power base games used by school principals. The scale was developed by Gencer, Tok and Ordu [59] based on Mintzberg's [8] "Political Games Theory"; it consists of six dimensions as sponsorship, alliance building, empire building, budgeting, expertise and lording. The scale consisting of 41 Likert-type items is answered between "1 strongly disagrees, 5 strongly agree". Increasing scores from the scale show that school principals use power base games. Cronbach Alpha reliability coefficients of subdimensions of the scale were reported to be between .81 and .98 . For this research the validity and reliability studies of the measurement tool were carried out again. The total variance explained by the six mentioned factors was found to be $64.61 \%$. In the exploratory factor analysis, it was determined that the factor load values differed between .46 and .83. As a result of the confirmatory factor analysis, the fit indices obtained were determined as $\chi^{2} / \mathrm{sd}=2.616$,
RMSEA $=.058, \quad \mathrm{CFI}=.92, \quad \mathrm{NFI}=.98, \quad \mathrm{GFI}=.85$, $\operatorname{TLI}(\mathrm{NNFI})=.91$ and IFI=.92. The Cronbach Alpha coefficients were found to be .88 in the sponsorship dimension, .72 in the alliance building dimension, .84 in the empire building dimension, .86 in the budgeting dimension, .87 in the expertise dimension, .95 in the lording dimension and .94 for the overall scale.

\subsubsection{Organizational Silence Scale}

This measuring instrument was developed by Van Dyne and et al. [22]. In this study, the scale was used as adapted to Turkish by Kahya [60]. The Likert-type scale which is rated between 1 (strongly disagree) and 5 (strongly agree) consists of 15 scale items and three subdimensions as acquiescent silence, defensive silence, prosocial silence. The increase in the scores from the scale shows that the organizational silence of the employees increases. Cronbach Alpha reliability coefficients of subdimensions of the scale were explained as between .80 and .88 . In the validity studies conducted for this study, it was found out that three factors explained $59 \%$ of the total variance and factor loads varied between .54 and .83 . According to the confirmatory factor analysis results, fit indices were calculated as $\chi^{2} / \mathrm{sd}=2.48$, GFI $=.95$, RMSEA $=.06, \mathrm{CFI}=.96$, $\mathrm{IFI}=.96, \mathrm{AGFI}=92, \mathrm{NFI}=.93$ and $\mathrm{TLI}=.95$. The Cronbach Alpha coefficients were found to be .75 for acquiescent silence, .88 for defensive silence, .74 for prosocial silence and .75 for the overall scale.

\subsubsection{Organizational Socialization Scale}

The scale was developed by Taormina [31] and it was updated by Taormina [34]. In this study, the scale was used as adapted to Turkish by Balc1, Baltac1, Fidan, Cereci and Acar [61]. The increasing scores from the scale show that the organizational socialization of the employees increases. The scale consists of 20 items and four sub dimensions as training, understanding, coworker support and future prospects. This Likert-type scale is graded between 1 (strongly disagree) - 5 (strongly agree). Cronbach Alpha coefficients for the dimensions ranged from .79 to .96 and for the overall scale it was found to be .77 . The total variance explained by the four factors in the validity studies for this study was found to be $63.21 \%$. In the exploratory factor analysis, it was determined that the factor loads changed between .42 and .81. As a result of the confirmatory factor analysis, fit indices were determined as $\chi^{2} / \mathrm{sd}=2.506$, RMSEA $=.057, \mathrm{CFI}=.95$, $\mathrm{NFI}=.92, \mathrm{GFI}=.93$, TLI $=.94, \mathrm{IFI}=.95$ and $\mathrm{AGFI}=.90$. Cronbach Alpha coefficients were found to be .90 in the training dimension, .75 in the understanding dimension, .83 in the coworker support dimension, .82 in the future prospects dimension and .90 for the overall scale.

\subsection{Analysis of the Data}

In the study, before analysing the data, carelessly filled 
forms were excluded from the analysis. Of the 552 scales that were determined as available after control 84 weren't included in the analysis because of their $z$ values $(z \geq 3)$; so, 468 scale forms were included in the analysis. The distribution of the data was determined by taking into account the kurtosis and skewness values of each variable. In a data set with normal distribution, the skewness and kurtosis values are supposed to be between -1 and +1 [62]. In this study, the skewness values were found between .013 and .621 , and the kurtosis values were between .030 and .571 . These findings indicate that normality of the data was provided. Whether there is a multicollinearity problem between multiple independent variables were determined by examining Variance Inflation Factor - VIF value. A VIF value higher than 10 indicates that there may be multicollinearity problem in the analysis [63]. In this study, the highest VIF value was calculated as 2.02 and the assumption of multicollinearity was also provided.

Descriptive statistics were used in the analysis of the research data, t-test was used in the paired comparisons, one-way variance analysis was used in three or more-category comparisons. In this study, Tukey test was used to determine the source of the difference for $F$ values that were significant because of the equality in the group variances [63]. In the interpretation of the descriptive statistics, total scores of the dimensions and scales were taken and a triple participation level was used as "low", "medium", "high". Structural Equation Model was used to determine in which level the sponsorship, alliance building, empire building, budgeting, expertise and lording games - subdimensions of the power base games used by school principals - predict the organizational silence and organizational socialization of teachers. In order to test the fit indices of the generated model, $\chi^{2} / \mathrm{sd}$, RMSEA, GFI, CFI, TLI, RMR, IFI and SRMR values were examined.

\section{Findings}

\subsection{Teachers' Perceptions of Power Base Games, Organizational Silence and Organizational Socialization}

Table 1 gives the statistical values and levels of participation that describe the teacher perceptions of the power base games used by school principals. When the values in Table 1 are examined, it is seen that the teachers responded to the entire power base games at a "medium" level with an average of 90.47. Teachers responded to the "budgeting" dimension at the highest level with an average of 28.27 and to the "lording" dimension at the lowest level with an average of 25.59 .

In Table 2, descriptive statistics values and participation levels of teachers' perceptions of organizational silence are given. Considering the values in Table 2, it is seen that teachers responded to the entire "organizational silence" at the "medium" level with an average of 38.22. Teachers responded to the "prosocial silence" dimension at the highest level with an average of 18.88 and to the "defensive silence" dimension at the lowest level with an average of 8.86 .

Table 1. Statistical values that describe the teachers' perceptions of power base games and their subdimensions

\begin{tabular}{|c|c|c|c|c|c|}
\hline & Minimum & Maksimum & Mean & Std. Deviation & Participation Level \\
\hline Sponsorship & 4 & 20 & 10.84 & 3.90 & Medium \\
\hline Alliance Building & 3 & 15 & 7.97 & 2.57 & Medium \\
\hline Empire Building & 3 & 15 & 7.21 & 2.67 & Medium \\
\hline Budgeting & 9 & 43 & 28.27 & 6.71 & Medium \\
\hline Expertise & 4 & 20 & 10.59 & 3.56 & Medium \\
\hline Lording & 12 & 56 & 25.59 & 9.77 & Low \\
\hline Power Base Games & 35 & 160 & 90.47 & 21.13 & Medium \\
\hline
\end{tabular}

Table 2. Statistical values of teachers' perceptions about organizational silence and its subdimensions

\begin{tabular}{|c|c|c|c|c|c|}
\hline & Minimum & Maksimum & Mean & Std. Deviation & Participation Level \\
\hline Acquiescent Silence & 5 & 22 & 10.48 & 3.07 & Low \\
\hline Defensive Silence & 5 & 19 & 8.86 & 2.83 & Low \\
\hline Prosocial Silence & 5 & 25 & 18.88 & 3.85 & High \\
\hline Organizational Silence Scale & 20 & 56 & 38.22 & 6.33 & Medium \\
\hline
\end{tabular}


In Table 3, descriptive statistics values and participation levels of teachers' perceptions of organizational socialization are given. In Table 3, it is seen that teachers responded to the entire "organizational socialization" at the "medium" level with an average of 67.31. It was determined that teachers responded to the "coworker support" dimension at the highest level with an average of 19.87 and to the "training" dimension at the lowest level with an average of 15.83 .

\subsection{Teachers' Perceptions of Power Base Games, Organizational Silence and Organizational Socialization in Terms of Gender, Branch, Occupational Seniority, the Type of School and the Length of Service at the Same School}

Teachers' perceptions of power base games used by school principals, organizational silence and organizational socialization in terms of gender variable are given in Table 4 . There are statistically significant differences between the perceptions of male and female teachers about the power base games used by school principals $(\mathrm{p}<.05)$. When compared to female teachers $(\bar{X}=87.00)$, male teachers $(\bar{X}=94.88)$ think that school principals use much more power base games. When Cohen $d$ value was examined, gender variable was found to have a "medium" effect size on power base games (.38). There was no statistically significant difference between female and male teachers' perceptions of organizational silence and organizational socialization ( $\mathrm{p}>.05)$.

Teachers' perceptions of power base games used by school principals, organizational silence and organizational socialization in terms of branch variable are given in Table 5. When Table 5 is examined, it is seen that non-math, math and science, classroom and other branch teachers have similar perceptions of power base games used by school principals and organizational socialization $(\mathrm{p}>.05)$. Statistically significant difference $(p<.05)$ was found between the perceptions of organizational silence of teachers in different branches. As a result of Post Hock Tukey test, significant differences were found between non-math course teachers and classroom teachers $(\mathrm{I}-\mathrm{J}=2.671, \mathrm{p}=.017)$; between non-math course teachers and other branch teachers $(\mathrm{I}-\mathrm{J}=2.775, \mathrm{p}=.014)$. It was determined that the means of non-math course teachers $(\bar{X}=40.32)$ are higher than the means of classroom teachers $(\bar{X}=37.65)$ and other branch teachers $(\bar{X}=37.54)$. According to the value of Eta-square $\left(\eta^{2}=.02\right)$, teachers' branch variable has a "small" effect on organizational silence behaviours.

Table 3. Statistical values of teachers' perceptions of organizational socialization and its subdimensions

\begin{tabular}{|c|c|c|c|c|c|}
\hline & Minimum & Maksimum & Mean & Std. Deviation & Participation Level \\
\hline Training & 6 & 25 & 15.83 & 4.26 & Medium \\
\hline Understanding & 9 & 20 & 15.51 & 2.47 & High \\
\hline Coworker Support & 9 & 25 & 19.87 & 3.03 & High \\
\hline Future Prospects & 5 & 25 & 16.10 & 4.26 & Medium \\
\hline Organizational SocializationScale & 35 & 95 & 67.31 & 10.79 & Medium \\
\hline
\end{tabular}

Table 4. Teachers' perceptions of power base games, organizational silence and organizational socialization in terms of gender

\begin{tabular}{|c|c|c|c|c|c|c|c|}
\hline & Gender & $\mathrm{n}$ & Mean & ss & $\mathrm{t}$ & $\mathrm{p}$ & Cohen $\mathrm{d}$ \\
\hline \multirow{2}{*}{ Power Base Games } & Female & 262 & 87.00 & 21.06 & \multirow{2}{*}{-4.074} & \multirow{2}{*}{$.000^{*}$} & \multirow{2}{*}{.38} \\
\hline & Male & 206 & 94.88 & 20.42 & & & \\
\hline \multirow{2}{*}{ Organizational Silence } & Female & 262 & 37.83 & 6.51 & \multirow{2}{*}{-1.479} & \multirow{2}{*}{.140} & \multirow{2}{*}{ - } \\
\hline & Male & 206 & 38.70 & 6.10 & & & \\
\hline \multirow{2}{*}{ Organizational Socialization } & Female & 262 & 18.98 & 3.82 & \multirow{2}{*}{.640} & \multirow{2}{*}{.523} & \multirow{2}{*}{-} \\
\hline & Male & 206 & 18.75 & 3.89 & & & \\
\hline
\end{tabular}

${ }^{*} \mathrm{p}<.05$ 
Table 5. Teachers' perceptions of power base games, organizational silence and organizational socialization in terms of branch

\begin{tabular}{|c|c|c|c|c|c|c|c|c|}
\hline & Branch & $\mathrm{n}$ & Mean & ss & $\mathrm{F}$ & $\mathrm{p}$ & $\begin{array}{c}\text { Paired } \\
\text { Difference }\end{array}$ & $\eta 2$ \\
\hline \multirow{4}{*}{ Power Base Games } & Non-math & 77 & 91.90 & 22.38 & \multirow{4}{*}{1.521} & \multirow{4}{*}{.208} & \multirow{4}{*}{ - } & \multirow{4}{*}{-} \\
\hline & $\begin{array}{l}\text { Math and } \\
\text { Science }\end{array}$ & 139 & 91.58 & 20.26 & & & & \\
\hline & Classroom & 130 & 91.72 & 19.90 & & & & \\
\hline & Other & 122 & 86.98 & 22.38 & & & & \\
\hline \multirow{4}{*}{$\begin{array}{l}\text { Organizational } \\
\text { Silence }\end{array}$} & Non-math & 77 & 40.32 & 6.63 & \multirow{4}{*}{3.700} & \multirow{4}{*}{$.012 *$} & \multirow{4}{*}{$\begin{array}{l}1-3 \\
1-4\end{array}$} & \multirow{4}{*}{.02} \\
\hline & $\begin{array}{l}\text { Math and } \\
\text { Science }\end{array}$ & 139 & 38.16 & 6.26 & & & & \\
\hline & Classroom & 130 & 37.65 & 5.80 & & & & \\
\hline & Other & 122 & 37.54 & 6.57 & & & & \\
\hline \multirow{4}{*}{ Organizational Socialization } & Non-math & 77 & 65.65 & 9.94 & \multirow{4}{*}{.824} & \multirow{4}{*}{.481} & \multirow{4}{*}{ - } & \multirow{4}{*}{ - } \\
\hline & $\begin{array}{l}\text { Math and } \\
\text { Science }\end{array}$ & 139 & 67.73 & 10.49 & & & & \\
\hline & Classroom & 130 & 67.23 & 10.74 & & & & \\
\hline & Other & 122 & 67.95 & 11.69 & & & & \\
\hline
\end{tabular}

Table 6. Teachers' perceptions of power base games, organizational silence and organizational socialization in terms of occupational seniority

\begin{tabular}{|c|c|c|c|c|c|c|c|c|}
\hline \multicolumn{2}{|c|}{ Occupational Seniority } & $\mathrm{n}$ & Mean & ss & $\mathrm{F}$ & $\mathrm{p}$ & $\begin{array}{c}\text { Paired } \\
\text { Difference }\end{array}$ & $\eta 2$ \\
\hline Power Base Games & $1-10$ years & 156 & 90.47 & 21.21 & \multirow{3}{*}{9.295} & \multirow{3}{*}{$.000^{*}$} & \multirow{3}{*}{$2-3$} & \multirow{3}{*}{.038} \\
\hline & $11-20$ years & 155 & 85.37 & 19.97 & & & & \\
\hline & 21 years and over & 157 & 95.50 & 21.07 & & & & \\
\hline \multirow[t]{3}{*}{ Organizational Silence } & $1-10$ years & 156 & 38.44 & 6.25 & \multirow{3}{*}{.150} & \multirow{3}{*}{.861} & \multirow{3}{*}{ - } & \multirow{3}{*}{ - } \\
\hline & $11-20$ years & 155 & 38.08 & 6.61 & & & & \\
\hline & 21 years and over & 157 & 38.12 & 6.19 & & & & \\
\hline \multirow[t]{3}{*}{ Organizational Socialization } & $1-10$ years & 156 & 65.58 & 10.50 & \multirow{3}{*}{3.973} & \multirow{3}{*}{$.019 *$} & \multirow{3}{*}{$1-3$} & \multirow{3}{*}{.017} \\
\hline & $11-20$ years & 155 & 67.34 & 11.09 & & & & \\
\hline & 21 years and over & 157 & 68.99 & 10.57 & & & & \\
\hline
\end{tabular}

${ }^{*} \mathrm{p}<.05$

Teachers' perceptions of power base games used by school principals, organizational silence and organizational socialization in terms of occupational seniority are given in Table 6. In terms of seniority variable, a significant difference was found between the perceptions of teachers who have 11-20 years of seniority and who have 21 years and over seniority $(\mathrm{I}-\mathrm{J}=10.135$, $\mathrm{p}=.000$ ) about the power base games used by school principals $(\mathrm{p}<.05)$. The means of the teachers having 21 years and over seniority $(\bar{X}=95.50)$ are higher than the means of the teachers having 11-21 years of seniority $(\bar{X}$ $=85.37)$. According to the Eta-square value $\left(\eta^{2}=.038\right)$, teachers' seniority variable has a "small" effect on the perceptions of power base games. While there wasn't any significant difference in the teachers' perceptions of organizational silence in terms of seniority variable $(p>.05)$, a significant difference was found in the teachers' perceptions of organizational socialization between the teachers who have 1-10 years seniority and who have 21 years and over seniority ( $\mathrm{I}-\mathrm{J}=3.417, \mathrm{p}=.014)$. The means of the teachers having 21 years and over seniority $(\bar{X}$ $=68.99)$ are higher than the means of the teachers having $1-10$ years seniority $(\bar{X}=65.58)$. According to eta square value $\left(\eta^{2}=.017\right)$, teachers' seniority variable has a "small" effect level on their organizational socialization.

Teachers' perceptions of power base games used by school principals, organizational silence and organizational socialization in terms of length of service at school are given in Table 7. When Table 7 was examined, it was seen that there was no significant difference between teachers' - who had different length of services in the same school - perceptions of power base games used by school principals and organizational silence $(p>.05)$, but in terms of organizational socialization there 
was a significant difference between the perceptions of teachers having 1-5 years of service length and 6-10 years of service length $(\mathrm{I}-\mathrm{J}=3.132, \mathrm{p}=.034)$. The means of the teachers having $1-5$ years of service length $(\bar{X}=66.27)$ are lower than the means of the teachers having 6-10 years of service length $(\bar{X}=69.41)$. According to Eta square value $\left(\eta^{2}=.018\right)$, teachers' length of service at school variable has a "small" effect level on their organizational socialization.

\subsection{The Effect of Teachers' Perceptions of Power Base Games Used by School Principals on Their Perceptions of Organizational Silence and Organizational Socialization}

The correlation values for variables were examined before the effect of the sponsorship, alliance building, empire building, budgeting, expertise and lording subdimensions of power base games on teachers' organizational silence and organizational socialization was examined. The findings are given in Table 8. It was seen that the subdimensions of power base games have significant relationships with each other. Moreover, alliance building, empire building, budgeting, expertise, lording dimensions have positively significant relationships with organizational silence; but sponsorship, empire building and lording dimensions have negatively significant relationships with organizational socialization.

Table 7. Teachers' perceptions of power base games, organizational silence and organizational socialization in terms of length of service at school

\begin{tabular}{|c|c|c|c|c|c|c|c|c|}
\hline & $\begin{array}{c}\text { Length of Service at } \\
\text { School }\end{array}$ & $\mathrm{n}$ & Mean & ss & $\mathrm{F}$ & $\mathrm{p}$ & $\begin{array}{c}\text { Paired } \\
\text { Difference }\end{array}$ & $\eta 2$ \\
\hline \multirow{3}{*}{ Power Base Games } & $1-5$ years & 310 & 89.71 & 21.83 & \multirow{3}{*}{2.739} & \multirow{3}{*}{.066} & \multirow{3}{*}{ - } & \multirow{3}{*}{-} \\
\hline & $6-10$ years & 96 & 89.19 & 19.12 & & & & \\
\hline & 11 years and over & 62 & 96.27 & 19.84 & & & & \\
\hline \multirow{3}{*}{ Organizational Silence } & $1-5$ years & 310 & 38.11 & 6.08 & \multirow{3}{*}{.159} & \multirow{3}{*}{.853} & \multirow{3}{*}{ - } & \multirow{3}{*}{-} \\
\hline & $6-10$ years & 96 & 38.34 & 7.10 & & & & \\
\hline & 11 years and over & 62 & 38.56 & 6.45 & & & & \\
\hline \multirow{3}{*}{$\begin{array}{c}\text { Organizational } \\
\text { Socialization }\end{array}$} & $1-5$ years & 310 & 66.27 & 10.71 & \multirow{3}{*}{4.276} & \multirow{3}{*}{$.014 *$} & \multirow{3}{*}{$1-2$} & \multirow{3}{*}{.018} \\
\hline & $6-10$ years & 96 & 69.41 & 11.44 & & & & \\
\hline & 11 years and over & 62 & 69.23 & 9.51 & & & & \\
\hline
\end{tabular}

$* \mathrm{p}<.05$

Table 8. Correlation values of the variables

\begin{tabular}{|c|c|c|c|c|c|c|c|}
\hline Variable & 1 & 2 & 3 & 4 & 5 & 6 & 7 \\
\hline Sponsorship (1) & & & & & & & \\
\hline Alliance Building (2) &, $515^{* *}$ & & & & & & \\
\hline Empire Building (3) &, $667^{* *}$ &, $517^{* *}$ & & & & & \\
\hline Budgeting (4) &, $354^{* *}$ &, $320^{* *}$ &, $380^{* *}$ & & & & \\
\hline Expertise (5) &, $384^{* *}$ &, $401^{* *}$ &, $515^{* *}$ &, $375^{* *}$ & & & \\
\hline Lording (6) &, $464^{* *}$ &, $395^{* *}$ &, $554^{* *}$ &, $190^{* *}$ &, $502^{* *}$ & & \\
\hline Organizational Silence (7) &, 067 &, $138^{* *}$ &, $101^{*}$ &, $104^{*}$ &, $138^{* *}$ & $.115^{*}$ & \\
\hline Organizational Socialization (8) &,$- 168^{* *}$ &,- 030 &,$- 113^{*}$ &, 060 & -002 & $-.237^{* *}$ & .021 \\
\hline
\end{tabular}

*Correlation is significant at .01 level.

**Correlation is significant at .05 level 


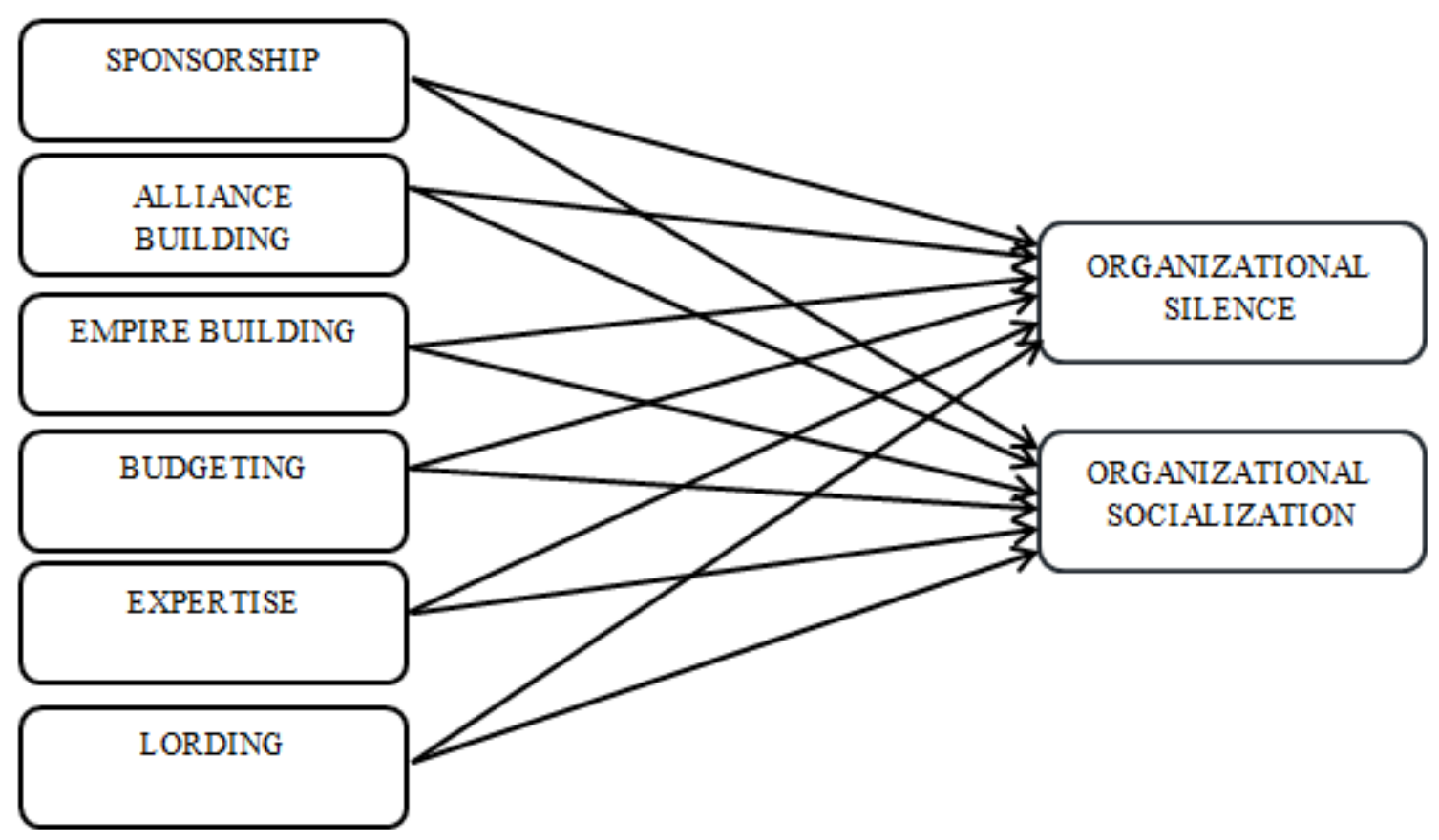

Figure 1. Research model

The model formed to determine the level at which the sponsorship, alliance building, empire building, budgeting, expertise and lording games used by school principals predict teachers' organizational silence and organizational socialization is presented in Figure 1.

Table 9. Fit Indices for measurement model

\begin{tabular}{|c|c|c|}
\hline Fit indicates & Fit Range & Research Model \\
\hline $\mathrm{X}^{2} / \mathrm{sd}$ & $0 \leq \mathrm{X}^{2} / \mathrm{sd} \leq 3$ & 2.028 \\
\hline $\mathrm{IFI}$ & $\leq 0.90$ & .92 \\
\hline $\mathrm{CFI}$ & $\leq 0.90$ & .92 \\
\hline RMSEA & $0.05 \leq \mathrm{RMSEA} \leq 0.08$ & .047 \\
\hline GFI & $\leq 0.90$ & .831 \\
\hline TLI & $\leq 0.90$ & .912 \\
\hline SRMR & \multirow{2}{*}{$0.05 \leq-\leq 0.10$} & .059 \\
\cline { 1 - 1 } RMR & & .061 \\
\hline
\end{tabular}

$\chi^{2} / \mathrm{df}$, IFI, CFI, RMSEA, GFI, TLI, SRMR and RMR values for the fit of the model obtained as a result of structural equation modeling which was formed to determine the effect of the subdimensions of the power base games used by school principals on teachers' organizational silence and organizational socialization are given in Table 9. As seen in Table 9, it can be said that the fit values of the research model are acceptable [64-66].

The significance, direction and standardized regression values of the relationships of the structural equation model are presented in Table 10. Considering Table 10, while there was a negatively significant relationship between sponsorship and organizational silence, alliance building and lording had a positively significant relationship with organizational silence. However, when the relationships between organizational silence and empire building, expertise and budgeting were examined, because $p$ value between the variables was above .05 and critical value was below the minimum required value (1.96) [67], it was possible to say that these games had no effect on organizational silence. On the other hand, there were negatively significant relationships between the sponsorship and lording games and organizational socialization. When the relationships between alliance building, empire building, expertise and budgeting games and organizational socialization were examined, because the regression coefficient between the variables was above .05 and critical value was below the minimum required value (1.96), it was possible to say that these games had no effect on organizational socialization. 
Table 10. Standardized regression coefficients of the research model

\begin{tabular}{|c|c|c|c|c|c|c|c|}
\hline Dependent Variable & & Independent Variable & Std. Value & $\begin{array}{c}\text { Std. } \\
\text { Error }\end{array}$ & $\begin{array}{c}\text { Critial } \\
\text { Value }\end{array}$ & $\begin{array}{c}\text { Acceptance } \\
\text { Status }\end{array}$ \\
\hline Org. Silence & $<---$ & Sponsorship & -.160 & .055 & -2.915 & $.004^{*}$ & Accepted \\
\hline Org. Silence & $<---$ & Alliance Building & .130 & .054 & 2.428 & $.015 *$ & Accepted \\
\hline Org. Silence & $<---$ & Empire Building & .043 & .084 & .509 & .611 & Refused \\
\hline Org. Silence & $<---$ & Budgeting & .036 & .049 & .725 & .725 & Refused \\
\hline Org. Silence & $<---$ & Expertise & -.004 & .035 & -.108 & .823 & Refused \\
\hline Org. Silence & $<---$ & Lording & .242 & .045 & 5.375 & $* * *$ & Accepted \\
\hline Org. Socialization & $<---$ & Sponsorship & -.228 & .088 & -2.595 & $.009 *$ & Accepted \\
\hline Org. Socialization & $<---$ & Alliance Building & -.017 & .085 & -.195 & .846 & Refused \\
\hline Org. Socialization & $<---$ & Empire Building & .167 & .137 & 1.221 & .222 & Refused \\
\hline Org. Socialization & $<---$ & Budgeting & .044 & .079 & .557 & .578 & Refused \\
\hline Org. Socialization & $<---$ & Expertise & .098 & .056 & 1.745 & .081 & Refused \\
\hline Org. Socialization & $<---$ & Lording & -.173 & .070 & -2.452 & $.014 *$ & Accepted \\
\hline
\end{tabular}

$* \mathrm{P}<.05, * * * \mathrm{P}<.001$

\section{Discussion and Conclusions}

In this study, it was aimed to determine the extent to which the power base games used by school principals predict teachers' organizational silence and organizational socialization. But first, descriptive analyzes related to these variables were conducted. Then, the differences according to the demographic variables were showed.

It was determined that the power base games used by school principals were at a medium level. Political games, defined as an effective means of reaching their own interests, are used by managers to protect their current position or to have more power. Education system is also a political system, and political games cannot be ignored in this system [12]. Similar to the results of this study, Medwick [12] has achieved the conclusion that political games can sometimes be seen in schools. Yazıcı and et. al [10] who examined political games at universities found that academicians do not prefer playing power base games. According to the results of the research, teachers think that school principals use budgeting games at most and lording games at least. School principals who display budgeting game can use this game because they will gain power when they provide more resources to their schools. Unlike the findings of this study, Korucuoğlu [56] reached the conclusion that among the power base games teachers perceived the alliance building and empire building games at most. In the lording game, individual may display various verbal mataphors, avowed discourse, stern and authoritarian tone of voice, and negative communication such as reprimand or humiliation to inform other individuals with whom he interacts that he himself is the boss [68]. In public schools, school principals may use lording game less which is based on pressure elements as teachers' salaries, dismissal, appointments, rights and responsibilities are determined by legislation.

In the study, it was found that teachers' organizational silence behaviours were at a medium level. This result shows that teachers cannot express their problems, inconveniences and suggestions they have experienced during the education process in detail. The silence behaviours of teachers may be due to the bureaucratic nature of schools, disagreement with the managers and the fear of isolation. However, schools are organizations with special status as the input and output of them is human being. The opinions, thoughts, concerns and recommendations of teachers seen as the most active employees in these special organizations should be guiding in the educational system. When the literature is examined, it is seen that other researchers' findings support this finding [69, 70]. Kahya [60], on the other hand, has reached the result that employees' level of organizational silence is high. The results of the research show that among the subdimensions of organizational silence, teachers use prosocial silence at the highest level. This result is consistent with the results of the studies in the literature $[60,69,71]$. Employees displaying prosocial silence try to conceal the information that can harm the image of the organization in order to benefit their organization and friends and to protect organization's reputation [72]. Because teachers protect their schools more than other employees and feel more devoted and loyal, they can keep their ideas, thoughts, knowledge and opinions in the cases where they feel that their schools and colleagues may suffer if they talk. In the research, it was found that teachers use defensive silence at least. When the literature is examined, it is seen that researchers have found results supporting this finding [60, 69, 71]. Defensive silence is the silence that the individual uses to protect himself, based on fear [22]. It can be said that 
teachers who are public employees do not use defensive silence behaviour because the possibility of losing their jobs is low.

In the research, it was found that teachers' organizational socialization was at a medium level. The study by Balc1 and et. al [61] supports this finding. The reasons why teachers' organizational socialization levels are lower than the expected are the difficulties in the training programs, not improving teachers' personal rights, the lack of opportunities to have career in the profession and not caring their opinions about the decisions on educational system. However, organizational socialization increases the work performance of employees [73, 74], their commitment to work [39, 42, 75], organizational commitment [40, 74, 76] and job satisfaction [76]. Increasing teachers' organizational socialization levels has a very important role for the schools to fulfill their goals efficiently and effectively. According to the results of the research, teachers responded to the coworker support dimension of the organizational socialization at the highest level. This result is consistent with the results of the other studies in the literature $[27,77]$. The principal's and other teachers' support is very important for teachers to learn the practices of the school, become active in teaching, understand their profession, become competent [78] and feel safe. Employees receiving support from managers and coworkers are more concerned with innovative behaviour [79], their organizational commitment [80] and job satisfaction increase and their emotional exhaustion decreases [81]. However, in their studies, Balc1 and et.al [61] reached the result that understanding dimension was at the highest level. Teachers stated that they agreed the training dimension at the lowest level. Yanık, Bağdat, Gelici and Taştepe [82] reached the conclusion that teachers associate their problems in classroom and time management, guidance, paperwork and relationships with parents to the undergraduate education that provides them limited experience. But in organizations, training has always been considered as an important part of human resources management and has a direct influence on employee performance [42] and job satisfaction [83]. For this reason, pre-service [78] and in-service training processes have an important role in teachers' becoming ready for school as a social structure, adapting to school and in providing organizational socialization in a short period of time. However, in their studies, Karasolak, Tanrıseven and Konokman [84] have found that teachers' attitudes towards in-service training are negative. It is thought that this result takes its source from the problems experienced during the planning, implementation and evaluation processes of in-service training programs in Turkey.

When the perceptions of the teachers about the power base games used by school principals were analyzed according to the gender variable, it was concluded that the perceptions of male teachers are higher than the perceptions of female teachers. Al-Tuhaih and Van Fleet [54] stated that women are not prone to see politics widely because of their low expectations and self-limiting behaviours. Ferris et al. [14] and Korucuoğlu [56] found that men perceived environment more politically as supporting the findings of this study. However, Vida and Cohen [85], Bodla and Danish [86], Nejad, Abbaszadeh and Hassani [87], Y1lmaz [88] and Donald, Bertha and Lucia [89] found that women perceived environment more politically. In their studies, Ferris and Kacmar [90], Parker, Dipboye and Jackson [91] and Kesgen [5] found that participants did not differ significantly in their political perceptions in terms of their gender. It was found out that there was not any significant difference between male and female teachers in their perceptions of organizational silence. This result may be due to the fact that teachers' professional roles are the same and they consider similar situations when they decide to remain silent. In the vast majority of studies on the subject, it was concluded that gender variable does not affect organizational silence as supporting the findings of this study [69, 92-95]. In the literature, there are also some studies which found that women are quieter; men make more dissentient voices to their superiors than women and easily express their opinions on the subject of work $[60,70,96,97]$. No significant difference was found between the male and female teachers' perceptions of organizational socialization. This finding reveals the importance of corporate socialization tactics. Although their genders are different, teachers may have similar perceptions because they share the same institution's socialization tactics. This result is consistent with the results of other studies $[78,98]$ in the literature. But Beheshtifar, Rashidi and Nekoie-Moghadam [99] found that male teachers' organizational socialization levels are higher.

Teachers working in different branches have similar perceptions about the power base games used by school principals. In her study, Medwick [12] also stated that classroom teachers, special education teachers and principals have similar perceptions of political games. In the research, it can be said that non-math courses' teachers showed more organizational silence behaviours than classroom and other courses' teachers. This result may be due to the fact that classroom teachers have more intensive communications due to their long working hours in the school. Similarly, in their studies, Kahveci and Demirtaş [100] found that classroom teachers showed less silence behaviour than branch teachers. In addition, other courses' teachers (physical education, music, visual arts, counselling, kindergarten, vocational school teachers) spend a long time through social activities they prepare. This situation can facilitate their stronger communication. It has been found that teachers in different branches have similar perceptions of organizational socialization behaviours. Although the branches of teachers are different, their benefiting from the same institutional 
facilities and sharing the same environment may explain the similarities in their perceptions of organizational socialization. The findings of Nartgün and Demirer [101] are parallel to this finding.

In the research, it was found out that the teachers with greater seniority perceived power base games used by school principals more than other teachers. The fact that senior teachers recognize the work environment and have more political abilities as a result of their experience can be shown as the reason for this. The studies of Vigoda and Cohen [85], Sultan, Kanwal and Gul [102] support this finding. However, İşcan [103] revealed that employees with more seniority had a lower perception of organizational politics; and Atinc, Darrat, Fuller and Parker [104], on the other hand, found out that there was not a significant difference between organizational politics perception and seniority variable. Teachers with different seniority have a similar perception of organizational silence. Fear of experiencing negative consequences, being characterized as a problematic person, lack of clarity in communication, lack of supportive management style in the exchange of ideas affect the way in which employees adopt or do not adopt the behaviour of silence [105]. Employees learn the behaviour of silence not only by trial and error, but also by observing and talking to colleagues [106]. For this reason, although they are in different seniorty groups, teachers may have similar perception of silence because they work with the same managers and share the same environment. This result is consistent with other studies' results in the literature $[93,95,100]$. It was determined that the teachers with greater seniority have a higher perception of organizational socialization. The acquisition of organizational socialization through a process can explain this finding. As their seniority increases, teachers learn their roles, adapt to the profession and the atmosphere; therefore, their organizational socialization levels increase. Similarly, Kartal [78], Beheshtifar et al. [99] have also revealed that individuals working in their professions for many years show more organizational socialization behaviours. However, Dal et al. [98] found out that there was not a significant difference between seniority and organizational socialization.

In the research, it was determined that teachers who worked at the same school in different periods of time perceived the power base games used by school principals similarly. This result may be due to the fact that teachers evaluated the behaviour of the same principal, although they worked in different periods of time. The studies of Doğan, Bozkurt and Demirbaş [107] support this finding. But in their studies Donald et al. [89] found out that as the length of service in the organization increases, the participants' perceptions of politics get higher. It was revealed that there was not a significant difference in the perceptions of teachers who worked in different periods of time in the same organization. Reasons why employees prefer to remain silent can be listed as; administrative and organizational causes, work-related fears, fear of isolation, fear of damage to relationships and national/cultural reasons [21]. Teachers who have different working periods in the school may have similar organizational silence behaviours because of working with the same manager and colleagues, and growing up in a common culture. This result is consistent with other studies' results $[92,94,95]$ in the literature. According to the results of the research, it was determined that organizational socialization perceptions of the teachers with little length of service in the school were lower. This result may be associated to the continuing nature of organizational socialization and teachers' learning the norms, values, roles of the school they are in; their gaining experience and strengthening their communication with colleagues over time.

In the study, it was found out that school principals' using lording and alliance building games predicts teachers' organizational silence in a positive way; but their using sponsorship game predicts in a negative way. Principals who use lording game can be oppressive and authoritarian by using their legal power over their subordinates [10]. Employees in organizations with authoritarian leadership structures that make it difficult for them to express themselves prefer organizational silence [108]. Because principals who use alliance building game form informal groups with the employees at the same level, other employees may prefer silence in order not to be excluded from these groups and not to be exposed to the sanctions of the groups. Spiral of silence by Noella-Neumann also emphasizes the repression that corresponds to the threat of isolation and the fear of abstraction that keeps people from being open about their thoughts [109]. The achievements of those using political games can have negative impacts on the perception of organizational trust, as it creates thought of inequality among other employees. In the organizations where the environment of trust cannot be provided, the culture of silence is dominant among the employees [110-113]. However, in the study, it was found out that when teachers perceived that school principals were using sponsorship game, their organizational silence behaviour would reduce. When sponsorship game which is defined as one's attaching himself to a person in the top position [12] is used, relationships with employees and community controlled by the sponsor can be fed [114] and thus, organizational silence may reduce. On the other hand, it was determined that school principals' using empire building, expertise and budgeting games did not interfere with teachers' voice behaviour. Generally speaking, because they require less strict management behaviours, these games may not be a barrier for teachers to express their ideas and suggestions.

In the research, it was determined that school principals' using lording and sponsorship games predicted 
organizational socialization of teachers negatively. Because they will resort to pressure, sanction and legitimization behaviours by using legitimate power, school principals who use lording game may obstruct teachers' organizational socialization. Mehtap [115] has stated that oppressive behaviours do not affect loyalty behaviour, awareness of responsibility, individuals' desire to improve themselves and functional participation positively. School principals who associate themselves with those in higher status by using sponsorship game [12] may block teachers' organizational socialization because they will show their loyalty and gratitude to the sponsor $[1,11]$. Because employees' organizational socialization is influenced by the behaviours of managers and the leadership styles they use [116]. The political games used can also slow the organizational socialization of employees, as they affect employee performance negatively [117-120]. But it was determined that school principals' using alliance building, empire building, expertise and budgeting games had no impact on teachers' organizational socialization. This result may be a sign that teachers perceive these games as more moderate political games.

\subsection{Recommendations}

Based on the results of the study, the following suggestions may be made: (1) to reduce the use of political games and power base games in schools, the ambiguity in the organizational system should be reduced. In this point, a system should be established where the merit and objective applications are realized in the practices such as rewarding, punishment, promotion and resource distribution. (2) In order to increase the communication power of the teachers, who are an effective element of intellectual capital, the communication channels in the schools should be kept open, a sincere organizational climate should be established, teachers should express their thoughts, ideas, concerns and suggestions related to their work and all teachers should be included in the decision process. (3) All stages of organizational socialization in the educational system must be put into practice completely. (4) Some studies can be made in which the effect of the political games on the functioning of educational institutions is searched with different parameters. (5) Much deeper studies can be made on political games with different research methods and patterns except for quantitative method.

\section{Acknowledgements}

This study was derived from Muharrem Gencer's doctoral dissertation titled "The Effect of Power Base Games on Organizational Silence and Organizational
Socialization".

\section{REFERENCES}

[1] J.G. Gibson, J.M. Ivancevich, J.H. Donnelly. Organizations, Business Publications, Illinois, 1988.

[2] K. Cacciattolo. Defining organisational politics, European Scientific Journal, August Special Edition, 238-246, 2014.

[3] Y. Samuel. The political agenda of organizations. NJ: Transaction Publishers, New Brunswick, 2005, (Electronic version,

https://books.google.com.tr/books?id=0pkCyv5J184C\&pg $=$ PR3\&hl $=$ tr\&source $=$ gbs_selected_pages\&cad $=2 \# \mathrm{v}=$ onep age \&q\&f=false).

[4] A. Balcı. Açıklamalı Eğitim Yönetimi Terimleri Sözlüğü, Pegem A Yayıncılık, Ankara, 2010.

[5] J. Kesgen. Örgütsel politika ve yansımaları, (Unpublished doctoral dissertation), Dokuz Eylül University, Institute of Social Sciences, İzmir, 1999.

[6] L. W. Porter, H. L. Angle, R. W. Allen. Organizational influence processes, N.Y.: Sharpe, Armonk, 2003, (Electronic version, https://books.google.com.tr/books?id= Y18YndoclYYC\&pg=PR3\&hl=tr\&source $=$ gbs_selected_p ages \&cad $=2 \# \mathrm{v}=$ onepage $\& \mathrm{q} \& \mathrm{f}=$ false $)$.

[7] W.K. Hoy, C.G. Miskel, Eğitim Yönetimi, (S. Turan, Cev.), Nobel Akademik Yayıncılık, Ankara, 2012.

[8] H. Mintzberg. Power in and around organizations, Englewood Cliffs: PrenticeHall, INJ.H, 1983, (Electronic version, http://www.mintzberg.org/).

[9] H. Mintzberg. The organization as political arena, Journal of Management Studies, Vol.22, No.2, 133-154, 1985.

[10] E. Yazıcı, Ş.S. Nartgün, T. Özhan. Political Games in Universities: A Case Study, Procedia - Social and Behavioral Sciences, Vol.174, 2700-2712, 2015.

[11] H. Mintzberg. Mintzberg on management, The Free Press, New York, 1989, (Electronic version, https://books.google.com.tr/books?id=9XOXVxN1GMsC $\&$ printsec $=$ frontcover $\& \mathrm{hl}=$ tr\&source $=$ gbs_ViewAPI\&redir _esc $=\mathrm{y} \# \mathrm{v}=$ onepage $\& \mathrm{q} \& \mathrm{f}=$ false).

[12] J. Medwick. An Analysis of the political games played between and among faculty at the K-5 or K-6 Elementary School Level, (Unpublished doctoral dissertation), Northern Illinois University, Illinois, 1996.

[13] S. Curtis. Lies, damned lies and organisational politics, Industrial and Commercial Training, Vol.35, No.7, 293-297, 2003.

[14] G.R. Ferris, D. Dwight, M.C.G. Frink, Z. Jing, K.M. Kacmar, J.L. Howard. Perceptions of organizational politics: Prediction, stress-related implications, and outcomes, Human Relations, Vol.49, No.2, 233-266, 1996.

[15] U. Rashid, N. Karim, S. Rashid, A. Usman. Employee's perception of organizational politics and its relationship with stress, Asian Journal of Business Management, Vol.5, 
No.4, 348-352, 2013.

[16] E.W. Morrison, F.J. Milliken. Organizational silence: A Barrier to change and development in a pluralistic World, Academy of Management Review, Vol.25, No.4, 706-725, 2000.

[17] C.C. Pinder, K.P. Harlos. Employee silence: Quiescense and acquiescence as responses to perceived injustice, Research in Personnel and Human Resources Management, Vol.20, 331-369, 2001.

[18] G. Kılıç, T. Tunç, S. Saraçlı, İ. Kılıç. Örgütsel stresin örgütsel sessizlik üzerine etkisi: Beş yıldızlı termal otel işletmelerinde bir uygulama, İşletme Araştırmaları Dergisi, Vol.5, No.1, 17-32, 2013.

[19] B. Panahi, S. Veiseh, S. Divkhar, F. Kamari. An empirical analysis on influencing factors on organizational silence and its relationship with employee's organizational commitment, Management Science Letters, Vol.2, No.3, 735-744, 2012.

[20] G. Bagheri, R. Zarei, M.N. Aeen. Organizational silence (Basic conceptsandits development factors), Ideal Type of Management, Vol.1, No.1, 47- 58, 2012.

[21] A. Çakıcı. Örgütlerde İşgören Sessizliği, Detay Yayıncılık, Ankara, 2010.

[22] L. Van Dyne, S. Ang, I.C. Botero. Conceptualizing employee silence and employee voice as multidimensional constructs, Journal of Management Studies, Vol.40, No.6, 1359-1392, 2003.

[23] H. Aktaş, E. Şimşek. Bireylerin örgütsel sessizlik tutumlarında iş doyumu ve duygusal tükenmişlik algılarının rolü, Uluslararası Yönetim İktisat ve İşletme Dergisi, Vol.11, No.24, 205-230, 2015.

[24] F. Tahmasebi, S.M. Sobhanipour, M. Aghaziarati. Burnout; explaining the role of organizational silence and its influence (case study: selected executive organizations of qom province), Journal of Basic and Applied Scientific Research, Vol.3, No.8, 272-282, 2013.

[25] S. Tangırala, R. Ramanujam. Employee silence on critical work issues: The Crosslevel effects of precedural justice climate, Personnel Psychology, Vol.61, 37-68, 2008.

[26] L.A. Perlow, S. Williams. Is silence killing your company?, Harward Business Review, Vol.31, No.4, 18-23, 2003.

[27] Ş. Çerik, S. Bozkurt. Çalışanların örgütsel sosyalizasyon ve kariyer çapalarına yönelik algılamaları arasındaki ilişkinin incelenmesi ve banka çalışanlarına yönelik bir araştırma, Erciyes Üniversitesi İktisadi ve İdari Bilimler Fakültesi Dergisi, Vol.35, 77-97, 2010.

[28] H. Darvish, B. Ashtiani, A.R. Kafashzadeh, S. Farid. Relation between socialization and organizational commitment: a survey between staff in headquarters of Keshavarzi Bank in I.R. Iran, Journal of American Science, Vol.8, No.10, 555-565, 2012.

[29] C.D. Fisher. Organizational socialization: An integrative review, Research in Personnel and Human Resource Management, Vol.4, 101-145, 1986.

[30] G.R. Jones. Socialization tactics, self-efficacy, and newcomers' adjustments to organizations, Academy of
Management Journal, Vol.29, 262-279, 1986.

[31] R.J. Taormina. The organizational socialization inventory, International Journal of Selection and Assessment, Vol.2, No.3, 133-145, 1994.

[32] R.J. Taormina. Organizational socialization: a multidomain, continuous process model, International Journal of Selection and Assessment, Vol.5, No.1, 29-47, 1997.

[33] A. Keser. İşletmelerde mesleki oryantasyon eğitimi ve verimlilik ilişkisi, İş Güç Endüstri İlişkileri ve İnsan Kaynakları Dergisi, Vol.1, No.1, 1999.

[34] R.J. Taormina, (2004). Convergent validation of two measures of organizational socialization, International Journal of Human Resource Management, Vol.15, No.1, 76-94, 2004.

[35] R.J. Taormina, C.M. Law. Approach stops preventing burnout: The effects of personal stress management and organizational socialization, Journal of Nursing Management, Vol.8, 89-99, 2000.

[36] M. Manzoor, H. Naeem. Relationship of organization socialization with organizational commitment and turnover intention: Moderating role of perceived organizational support. Interdisciplinary Journal of Contemporary Research in Business, Vol.3, No.8, 515-529, 2011.

[37] P.E. Madlock, S.M. Horan. Predicted outcome value of organizational commitment, Communication Research Reports, Vol.26, No.1, 40-49, 2009.

[38] A. Balc1. Açıklamalı eğitim yönetimi terimleri sözlüğü, Pegem A Yayıncılık, Ankara. 2010.

[39] A. Cohen, A. Veled-Hecht. The relationship between organizational socialization and commitment in the workplace among employees in long-term nursing care facilities, Personnel Review, Vol.39, No.5, 537-556, 2010.

[40] M.C. Vallejo, D. Langa. Effects of family socialization in the organizational commitment of the family firms from the moral economy perspective, Journal of Business Ethics, Vol.96, No.1, 49-62, 2010.

[41] S.A. Afsanepurak, R.N.S. Hossini, M.K. Seyfari, Z.M Nasab. The relationship between organizational socialization and organizational commitment in physical education departments employees in Mazandaran-Iran, International Journal of Academic Research in Business and Social Sciences, Vol.2, No.1, 187-195, 2012.

[42] J. Gao. A model of organizational socialization and turnover intention, International Journal of E-Business Development, Vol.1, No.1, 22-25, 2011.

[43] J. Van Maanen. Police socialization: A longitudinal examination of job attitudes in an urban police department, Administrative Science Quarterly, Vol.20, 207-228, 1975.

[44] A.L. Kristof. Person-organization fit: An integrative review of its conceptualizations, measurement, and implications, Personel Psychology, Vol.49, No.1, 1-49, 1996.

[45] A. Cooper-Thomas, N. Anderson. Newcomer adjustment: The relationship between organizational socialization tactics, information acquisition and attitudes, Journal of Occupational and Organizational Psychology, 75, 423-437, 2002. 
[46] Jaskyte, K. The impact of organizational socialization tactics on role ambiguity and role conflict of newly hired social workers. Administration in Social Work, Vol.29, No.4, 69-87, 2005

[47] S. Atay. Geliştirilebilir yönetim becerisi: Teorik ve ampirik yönleriyle "Politik Yeti", Amme İdaresi Dergisi, Vol.43, No.2, 65-80, 2010

[48] S.M. Al-Tuhaih, D.D. Van Fleet. An exploratory study of organizational politics in Kuwait, Thunderbird International Business Review, Vol.53, No.1, 93-104, 2011.

[49] J. Blase. The Micropolitics of Effective School-Based Leadership: Teachers' Perspectives, Educational Administration Quarterly, Vol.29, No.2, 142 - 163, 1993.

[50] A. Hargreaves. Extending Educational Change, Springer, Netherlands, 2005.

[51] A. Akçekoce, K.U. Bilgin. Okul Müdürlerinin Liderlik Stilleri ve Öğretmen Performans1, Journal of Contemporary Administrative Science, Vol.2, No.2, 1-23, 2016.

[52] B. Bilge. Öğrenci Başarısını Arttırmada Okul Müdüründen Beklenen Liderlik Özellikleri, Anadolu Eğitim Liderliği ve Öğretim Dergisi, Vol.1, No.2, 12 - 23, 2013.

[53] A. Avcı. Öğretmen Algılarına Göre Okul Müdürlerinin Liderlik Stilleri, Hasan Ali Yücel Eğitim Fakültesi Dergisi, Vol.12-2, No.24, 161-189, 2015.

[54] L. G. Bolman, T. E. Deal. Organizasyonları yeniden yapılandırmak. (Translated: A. Aypay, A. Tanrı̈ğen) Seçkin Yayıncılık, Ankara, 2013.

[55] M. Karademir, A. Cillioğlu Karademir. Political behavior and Mintzberg's Political Games: Example of organized criminal 1nstitutions with Godfather Film analysis, European Scientific Journal, Vol.11, No.14, 1-22, 2015.

[56] T. Korucuoğlu. Örgütsel güç oyunları ve örgütsel muhalefet arasındaki ilişki, (Unpublished master thesis). Eskişehir Osmangazi University, Institute of Education Sciences, Eskişehir, 2016.

[57] N. Karasar. Bilimsel Araştırma Yöntemi, Nobel Yayın Dağıtım, Ankara, 2017.

[58] A. Balcı. Sosyal bilimlerde araştırma yöntem, teknik ve ilkeler, Pegem Yayıncılık, Ankara, 2001.

[59] M. Gencer, T.N. Tok, A. Ordu. Power Base Games That School Principles Use Scale: Its Development, Validity and Reliability, International Journal of Assessment Tools in Education, Vol.5, No.2, 274-288, 2018.

[60] C. Kâhya. Dönüştürücü ve etkileşimci liderlik anlayışları ile örgütsel sessizlik arasındaki ilișkide örgütsel güvenin rolü, (Unpublished doctoral dissertation), Atatürk University, Institute of Social Sciences, Erzurum, 2013.

[61] A. Balcı, A. Baltacı, T. Fidan, C. Cereci, U. Acar. Örgütsel sosyalleşmenin, örgütsel özdeşleşme ve örgütsel vatandaşlıkla ilişkisi: İlköğretim okulu yöneticileri üzerinde bir araştırma, Eğitim Bilimleri Araştırmaları Dergisi, Vol.2, No.2, 47-74, 2012.

[62] S.W. Huck. Reading Statistics and Research, Boston, Pearson, 2008, (Electronic version, https://pendbingikgs.files.wordpress.com/2016/12/reading- statistics-and-research-sixth-edition.pdf).

[63] Ş. Büyüköztürk, Sosyal bilimler için veri analizi el kitabı, Pegem Akademi, Ankara, 2017.

[64] D. Hooper, J. Coughlan, M. Mullen. Structural equation modelling: guidelines for determining model fit, Electronic Journal of Business Research Methods, Vol.6, No.1, 53-60, 2008.

[65] L. Hu, P.M. Bentler. Cutoff criteria for fit indexes in covariance structure analysis: Conventional criteria versus new alternatives, Structural Equation Modeling: A Multidisciplinary Journal, Vol.6, No.1, 1-55, 1999.

[66] K. Schermelleh-Engel, H. Moosbrugger, H. Müller. Evaluating the fit of structural equation models: Test of significance and descriptive goodness-of-fit measures, Methods of Psychological Research, Vol.8, No.2, 23-74, 2003.

[67] N. Bayram. Yapısal eşitlik modellemesine giriş AMOS uygulamaları, Ezgi Kitabevi, Bursa, 2016.

[68] N. Oyman. Türk yükseköğretim kurumlarındaki güç ilişkilerinin alan kuramı ve dramaturjik yaklaşım bağlamında incelenmesi, (Unpublished doctoral dissertation), Eskişehir Osmangazi University, Institute of Education Sciences, Eskişehir, 2016.

[69] Y. Ünlü, M.A. Hamedoğlu, E. Yaman. Öğretmenlerin örgütsel adalet algıları ve örgütsel sessizlik düzeyleri arasındaki ilişki, Sakarya University Journal of Education, Vol.5, No.2, 140-157, 2015.

[70] A. Çiçek Sağlam, A. Yüksel. Liselerde görev yapan öğretmen ve yöneticilerin örgütsel sessizliğe ilişkin görüssleri, International Periodical For the Languages, Vol.10, No.7, 317-332, 2015.

[71] D. Ürek, İ. Bilgin Demir, Ö. Uğurluoğlu. Örgütsel sessizliğin örgütsel vatandaşlık davranıșı üzerindeki etkisi: Bir eğitim ve araştırma hastanesi uygulaması, Gazi Üniversitesi İktisadi ve İdari Bilimler Fakültesi Dergisi, Vol.17, No.3, 122-141, 2015.

[72] A.T. Dedahanov, C. Kim, J. Rhee. Centralization and communication opportunities as predictors of acquiescent or prosocial silence, Social Behavior and Personality: An International Journal, Vol.43, 481-492, 2015.

[73] T.N. Bauer, S.G. Green. Effect of newcomer involvement in work-related activities: a longitudinal study of socialization, Journal of Applied Psychology, Vol.79, No.2, 211-223, 1994.

[74] T.N. Bauer, T. Bodner, B. Erdogan, D.M. Truxillo, J.S Tucker. Newcomer adjustment during organizational socialization: a meta-analytic review of antecedents, outcomes, and methodsi, Journal of Applied Psychology, Vol.92, No.3, 707-721, 2007.

[75] M. Judeh. Role ambiguity and role conflict as mediators of the relationship between orientation and organizational commitment, International Business Research, Vol.4, No.3, $171-181,2011$

[76] B.E. Ashforth, A. M. Saks. Socialization tactics: Longitudinal events on newcomers adjustment, Academy of Management Journal, Vol.39, 149-178, 1996. 
[77] B. Burgaz, S. Koçak, H. Büyükgöze. Öğretmenlerin mesleki ve bürokratik sosyalleştirmeye yönelik değerlendirmeleri, Hacettepe Üniversitesi Eğitim Fakültesi Dergisi, Özel Say1 1, 39-54, 2013.

[78] S. Kartal. İlköğretim okulu yönetici ve öğretmenlerinin örgütsel sosyalleşme düzeyleri, (Unpublished doctoral dissertation), Ankara University, Institute of Education Sciences, Ankara, 2003.

[79] V. Arora, T.J. Kamalanabhan. Linking supervisor and coworker support to employee innovative behavior at work: Role of psychological conditions, Academic and Business Research Institute International Conference proceedings, New Orleans, 2013.

[80] B. Woo, P. Chelladurai. Dynamics of perceived support and work attitudes: The case of fitness club employees, Human Resource Management Research, Vol.2, No.1, 6-18, 2012.

[81] P. Charoensukmongkol, M. Moqbel, S. Gutierrez-Wirsching. The role of co-worker and supervisor support on job burnout and job satisfaction, Journal of Advances in Management Research, Vol.13, No.1, 4-22, 2016.

[82] H.B. Yanık, O. Bağdat, Ö. Gelici, M. Taştepe. Göreve yeni başlayan ortaokul matematik öğretmenlerinin karşılaştıkları zorluklar, Mustafa Kemal Üniversitesi Sosyal Bilimler Enstitüsü Dergisi, Vol.13, No.36, 130-152, 2016.

[83] V. Tabvuma, Y. Georgellis, T. Lange. Orientation training and job satisfaction: A sector and gender analysis, Human Resource Management, Vol.54, No.2, 303-321, 2014.

[84] K. Karasolak, I. Tanrıseven, G.Y. Konokman. Öğretmenlerin hizmetiçi eğitim etkinliklerine ilişkin tutumlarının belirlenmesi, Kastamonu Eğitim Dergisi, Vol.21, No.3, 997-1010, 2013.

[85] E. Vigoda, A. Cohen. Influence tactics and perceptions of organizational politics a longitudinal study, Journal of Business Research, Vol.55, 311-324, 2002.

[86] M.A. Bodla, R.Q. Danish. The gender differences in the relationship between perceptions of organizational politics and work performance, International Journal of Knowledge Culture and Change Management, Vol.8, No.6, 9-18, 2008.

[87] B.A. Nejad, M.M.S. Abbaszadeh, M. Hassani. Organizational political tactics in universities, Higher Education Studies, Vol.1, No.2, 65-72, 2011.

[88] O.D. Y1lmaz. Perception of organizational politics and 1mpression management behaviors: A tourism industry perspective, International Journal of Business and Social Science, Vol.5, No.8, 98-109, 2014.

[89] M.F. Donald, L. Bertha, M.E. Lucia. Perceived organzational politics influences on organizational commitment among supporting staff members at a selected higher education institution, The 2016 Wei International Academic Conference Proceedings, Vienna, Austria, 2016.

[90] G.R. Ferris, K.M. Kacmar. Perceptions of organizational politics, Journal of Management, Vol.18, 93-116, 1992.

[91] P.C. Parker, R.L. Dipboye, S.L. Jackson. Perceptions of organizational politics: An investigation of antencedents and consequences, Journal of Management, Vol.21, No.5, 891-912, 1995.
[92] S..S. Nartgün, S. Demirer. Öğretmenlerin örgütsel sessizlik ile iş yaşamında yalnızlık düzeylerine ilişkin görüşleri, Bayburt Üniversitesi Eğitim Fakültesi Dergisi, Vol.7, No.2, 139-156, 2012.

[93] L. Özdemir, S. Sarığlu Uğur. Çalışanların “örgütsel ses ve sessizlik" algılamalarının demografik nitelikler açısından değerlendirilmesi: Kamu ve özel sektörde bir araştırma, Atatürk Üniversitesi İktisadi ve İdari Bilimler Dergisi, Vol.27, No.1, 257-281, 2013.

[94] A.S. Köylüoğlu, A. Bedük, L. Duman, H.H Büyükbayraktar. Analyzing the relation between teachers' organizational silence perception and whistle blowing perception, Procedia - Social and Behavioral Sciences, Vol.207, 536-545, 2015.

[95] E. Önder. Ortaöğretim okullarında örgütsel sessizliğin yordayıcıs1 olarak örgütsel adalet ve örgütsel bağlılık, Kırşehir Eğitim Fakültesi Dergisi, Vol.18, No.2, 669-686, 2017.

[96] P. Boufounou, K. Avdi. Financial crisis, organizational behavior and organizational silence in the public sector: A case study for Greece, SPOUDAI Journal of Economics and Business, Vol.66, No.1-2, 46-78, 2016.

[97] J. LePine, L. Van Dyne. Predicting voice behavior in work groups, Journal of Applied Psychology, Vol.83, No.6, 853-868, 1998

[98] A. Dal, G. Hergüner, F. Güven, R. Erdal, A.B. Ertekin. Levels of organizational socialization in sports companies, IIB International Refereed Academic Social Sciences Journal, Vol.8, 85-99, 2012.

[99] M. Beheshtifar, M. Rashidi, M. Nekoie-Moghadam. Study of organizational socialization and its relationship on employees' performance, African Journal of Business Management, Vol.5, No.26, 10540-10544, 2011.

[100]G. Kahveci, Z. Demirtaş. Öğretmenler için örgütsel sessizlik ölçeği geliştirme çalışması, Elektronik Sosyal Bilimler Dergisi, Vol.12, No.43, 167-182, 2013.

[101] Ș.S. Nartgün, S. Demirer. Öğretmenlerin örgütsel sosyalleşme ve özdeşleşme düzeyleri ile birlikte çalışma yeterlikleri arasındaki ilişki, Abant İzzet Baysal Üniversitesi Eğitim Fakültesi Dergisi, Vol.16, No.1, 237-269, 2016

[102] S. Sultan, F. Kanwal, S. Gul. Factors of Perceived Organizational Politics: An Analysis of What Contributes the Most?, Pakistan Journal of Commerce and Social Sciences, Vol.9, No.3, 999-1011, 2015.

[103] Ö.F. İşcan. Siyasal arena metaforu olarak örgütler ve örgütsel siyasetin örgütsel adalet algisına etkisi, Ankara Üniversitesi SBF Dergisi, Vol.60, No.1, 149-171, 2005.

[104] G. Atinc, M. Darrat, B. Fuller, B.W. Parker. Perceptions of organizational politics: a meta-analysis of theoretical antecedents, Journal of Managerial Issues, Vol.22, No.4, 494-513, 2010.

[105] M. Vakola, D. Bouradas. Antecedents and consequences of organizational silence: An empirical investigation, Employee Relations, 441-458, 2005.

[106]F.J. Milliken, E.W. Morrison, P.E. Hewlin. An exploratory study of employee silence: issues that employees don't 
communicate upward and why, Journal of Management Studies, Vol.40, No.6, 1453 - 1476, 2003.

[107] A. Doğan, S. Bozkurt, T. Demirbaş. Kamu örgütlerinde örgütsel politika: çalıșanların politik davranışlara yönelik algıları, Akademik Bakış Dergisi Uluslararası Hakemli Sosyal Bilimler Dergisi, Vol.44, 1-25, 2014.

[108] Y. Zhang, M.Y. Huai, Y.H. Xie. Paternalistic leadership and employee voice in China: A dual process model, The Leadership Quarterly, Vol.26, No.1, 25-36, 2015.

[109]F. Bowen, K. Blackmon. Spirals of silence: The dynamic effects of diversity on organizational voice, Journal of Management Studies, Vol.40, No.6, 1393- 1417, 2003.

[110]X.T. Zheng, J.L. Ke, J.T. Shi, X.S. Zheng. Survey on employee silence and the impact of trust on it in China. Acta Psychologica Sinica, Vol.40, No.2, 219-227, 2008.

[111] A.K. Cakinberk, N.P. Dede, G. Yilmaz. Relationship between organizational trust and organizational silence: An example of public university, Journal of Economics Finance and Accounting, Vol.1, No.2, 91-105, 2014.

[112] A. Çiçek Sağlam. The effects of vocational high school teachers' perceived trust on organizational silence, Journal of Education and Training Studies, Vol.4, No.5, 225-232, 2016.

[113] Ö. Paşa, A. Negiş Işık. Öğretmenlerin okul müdürüne güven düzeyleri ve okul müdürü tarafindan sergilenen etik liderlik davranışlarının örgütsel sessizlik üzerindeki etkisi, Elektronik Sosyal Bilimler Dergisi, Vol.16, No.60, 134-144,
2017.

[114] T. B. Cornwell, I. Maignan. An international review of sponsorship research, Journal of Advertising, Vol.27, No.1, 1-21, 1998.

[115] Ö. Mehtap. Örgüt içi politik davranışların örgütsel vatandaşlık davranışı üzerindeki etkisi, (Unpublished doctoral dissertation), Istanbul University, Institute of Social Sciences, İstanbul, 2011.

[116]F. Nasser-Abu Alhija, B. Fresko. Mentoring of new teachers: Correlates of activities and mentors' attitudes, Procedia Social and Behavioral Sciences, Vol.2, 24972500, 2010.

[117]P. Kumar, R. Ghadially. Organizational politics and its effects on members of organizations, Human Relations, Vol.42, No.4, 305-314, 1989.

[118][E. Vigoda. The relationship between organizational politics, job attitudes, and work outcomes: Exploration and implications for the public sector, Journal of Vocational Behavior, Vol.57, 326-347, 2000.

[119] K.E. Ugwu, M.O. Ndugbu, L. Okoroji, L.A.U. Kalu. Organizational politics and employees' performance in private sector investment: A comparative study of Zenith Bank Plc. and Alcon Plc. Nigeria, European Journal of Business and Management, Vol.6, No.26, 103-114, 2014.

$[120]$ S. Khalid, S. Ishaq. Job related outcomes in relation to perceived organizational politics, Pakistan Economic and Social Review, Vol.53, No.1, 133-148, 2015. 